\title{
An Optimal Model for Designing and Executing Windows in Tabriz Residential Buildings to Reduce Energy Consumption
}

\author{
S. Abdoli Naser ${ }^{1}$, F. Haghparast ${ }^{2 *}$, M. Singery ${ }^{3}$, H. Sattari Sarbangholi ${ }^{3}$ \\ ${ }^{1}$ Department of Architecture, Tabriz Branch, Islamic Azad University, Tabriz, Iran \\ ${ }^{2}$ Faculty of Architecture and Urbanism, Tabriz Islamic Art University, Tabriz, Iran \\ ${ }^{3}$ Department of Architecture and Urbanism, Tabriz Branch, Islamic Azad University, Tabriz, Iran
}

\section{$P A P E R$ IN FO}

Paper history:

Received 14 August 2021

Accepted in revised form 11 January 2022

\section{Keywords:}

Energy consumption

Parametric optimization

Genetic algorithm

Window

Cold and dry climate of Tabriz

\section{$A B S T R$ A $C T$}

Most of today's buildings, due to improper imitation of the architecture of buildings in other countries, are forced to use more energy to create conditions of thermal comfort. Building windows affect energy efficiency. So, the aim of this research is to be concerned with Tabriz climate; in selecting the proportion and suitable glazing of the windows, in order to access the best design and execute a model to decrease energy consumption. The research approach is to utilize simulation and Design Builder software as a research tool. So, the annual gas consumed in the Building was received from the National Iranian Gas Company and a case study is modeled and after converting the unit from $\mathrm{kWh}$ to $\mathrm{kg}$ and $\mathrm{kg}$ to $\mathrm{m}^{3}$ and reliability of simulation results. Then, through parametric optimization, eight scenarios in designing windows and through the genetic algorithm, the glazing coating were evaluated. The simulations were performed again and the results index was examined. Eventually, based on the analysis of outputs, according to fixed area, it is more suitable to replace windows with the height of 1.5 to 1.74 meters instead of windows with the height of 1 or 1.2 meters. A window should be replaced with 2, 3, 4 or 5 windows with the same fixed area. I is desired to superseded triple-glazed glazing with lowemissivity filled with argon gas with clear double-glazed glazing filled with air to reduce energy consumption. The amount of heat losses for the window height of 1 to $1.5 \mathrm{~m}$, from one window to five windows and for the clear double-glazed glazing filled with air were $2.04 \%, 11.11 \%$, and $45.36 \%$, respectively.

doi: 10.5829/ijee.2022.13.01.04

\section{NOMENCLATURE}

\begin{tabular}{llll}
\hline U-Value & $\mathrm{W} / \mathrm{m}^{2} \mathrm{k}$ & UPVC & Unplasticized Poly Vinyl Choride \\
R-Value & $\mathrm{m}^{2} \mathrm{k} / \mathrm{W}$ & HVAC & Heating, Ventilation, Air Conditioning \\
SHGC & Solar Heat Gain Coefficient & DHW & Domestic Hot Water \\
$\mathrm{T}_{\mathrm{v}}$ & Visible Transmittance & WWR & Window-to-Wall Ratio \\
\hline
\end{tabular}

\section{INTRODUCTION}

According to the literature, $78 \%$ of the world's energy consumption is depending on fossil fuels [1]. Based on implemented researches, buildings consume about $40 \%$ of the total ultimate fossil fuel [2]. Residential energy consumption represents more than a quarter of building fossil fuel consumption [3].

However, the thermal performance of glazing systems is generally very poor due to the large heat transfer coefficient and small thermal mass [4]. Besides, the cold and dry climate of Tabriz needs high energy consumption

\footnotetext{
*Corresponding Author Email: f.haghparast@tabriziau.ac.ir 
for heating. Diverse researches have been done in the field of optimal proportions for designing windows which are provided based on historical concepts.

Zekraoui and Zemmouri [5] investigated the effect of window specifications on the building energy demand. Results show that orientation had a large effect on the energy loads.

Lechowska et al. [6] centralized on the window frames. Simulated results show that the air gap filling with polyurethane foam in window frames can reduce heat loss of frames by about $27 \%$.

Khalesi and Goudarzi [7] assessed smart windows. It can be concluded from the results that substitution of clear glazing with smart electrochromic glazing; window-towall ratio (WWR) can be an enhancement.

Hasan et al. [8] focused on building simulation. They came to the conclusion that WWR should be determined based on its floor area.

Potrc et al. [9] studied the best orientation of windows. South front, with a swirl of about 1-24 degrees, is suitable for the windows to get maximum availability to solar energy.

Kaasalainen et al. [10] focused on the architectural window design. They concluded from the outputs that increasing window size on average also increased energy consumption, especially in cold conditions.

Zhou and Zheng [11] studied aerogel glazings and found that the aerogel granulate glazing systems can reduce heat flux.

Abdoli Naser et al. [12] studied the optimal execution model for windows. For optimization, triple-glazed glazing with low emission coating $\mathrm{e}=0.1$ is recommended.

Saadatian et al. [13] investigated window systems and found that winter-appropriate glass is triple-glazed glazing.

Jiang et al. [14] assessed residential energy consumption in cold climates. Results indicated that the north WWR of the residence should not be less than 0.1 .

Sadafi et al. [15] concentrated on the optimization of building envelopes. It can be concluded from the results that the larger WWRs improve factors such as view and natural lighting. On the other hand, the smaller WWRs, address privacy and energy saving.

Abdoli Naser et al. [16] assessed on the thermal performance of windows in intermediate housing. They found that the gas consumption is reduced if the WWR decreased from $50 \%$ to $20 \%$.

Huang et al. [17] concentrated on vacuum glazing. They concluded from the outputs that vacuum glazings save more energy consumption in terms of heating and cooling load.

Tushar et al. [18] studied the window systems. Analysis specifies the provision of glazing $40-68 \%$ of WWR feasible for optimal trade-offs.

Abdoli Naser et al. [19] studied on the evolution of windows from Qajar to Pahlavi era. They concluded from the outputs that by minimizing the area of the openings (WWR), the amount of heat transfer during the cold winter of Tabriz is reduced.

Bagheri Sabzevar and Erfan [20] investigated on effect of shading devices on thermal efficiency and found that in terms of thermal efficiency, the distance between the blinds on the south facade and the angle between them on the east and west facades of a window louver are the most significant factors.

The contents show this fact; research about windows; fundamentally is about suitable orientation for windows, the better location of the window in building facades, and the ratio of the total area of the window to the shell. The discrepancy and innovation of the present research can be intended in the assessment of the impact of window proportion, a number of windows by considering a fixed area (total area-fixed-for window- (fixed WWR)) and the number of glazings, coating, the gas between glazing of windows on the quantity of heat dissipation in the translucent walls of the residential buildings and annual natural gas consumed for heating.

So, the aim of this research is to provide adequate proportion and glazing for windows in Tabriz residential buildings to decrease energy consumption.

\section{RESEARCH METHODOLOGY}

The work is based on the objectives of the research, of the type of "application" and also based on the nature. This is "simulation" and will be based on logical reasoning. The research method is quantitative. The statistical society is a residential building in Tabriz and the objective society is the gas consumption for heating the building. The autonomous variable of the research will be different window proportions of design models and the affiliate variable will be the amount of natural gas and annual electricity consuptions for heating and cooling the building.

The first action in this research procedure is collection of data. Climatic data of Tabriz city has been received from Tabriz Meteorological Department and building physics data such as plan and HVAC system, building facade by field survey in the building; collected. The proceeding of simulation in EnergyPlus engine and gaining results in the DesignBuilder software is as follows:

1. Entering the climatic data of Tabriz (The average climate of 11 years);

2. 3-D modeling of the building;

3. Enter fixed specifications of the building (executive details, windows specifications, HVAC system).

After importation of the fixed specifications of the basic research model and it's simulation on the EnergyPlus engine, the amount of gas used for heating will be received from the National Iranian Gas Company to Reliability the accuracy of the results obtained from the 
DesignBuilder software. Then, the form and number of windows (fixed area for the windows) will be changed and the building simulation will be executed according to the mentioned changes. Figure 1 shows the implementation model of the research.

\section{Reason for choosing DesignBuilder software}

A building energy simulation technique using DesignBuilder software (EnergyPlus simulation engine) will be used to estimate heating, cooling, and total energy requirements. The simulated daily consumption compared better with daily measured consumption. The maximum error is about 5\% in cooling load and 3\% in heating load [21]. For the above reason, this software has been selected for simulation.

\section{Average climate of Tabriz (11-years)}

The average minimum, average and maximum air temperature of Tabriz Synoptic Station in the statistical period of 2009-2020 on a monthly time scale are presented in Figure 2.

\section{Basic research model}

In order to study and test the research variables, it is necessary to simulate the model to measure the impact of variables. The simulated model is located in Tabriz (Figure 3). The model is a residential building and has a rotation of 35 degrees to the southwest as can be seen in Figure 3. The building is located on a plot of land with an area of $420 \mathrm{~m}^{2}$. The building has an area of $237.5 \mathrm{~m}^{2}$.

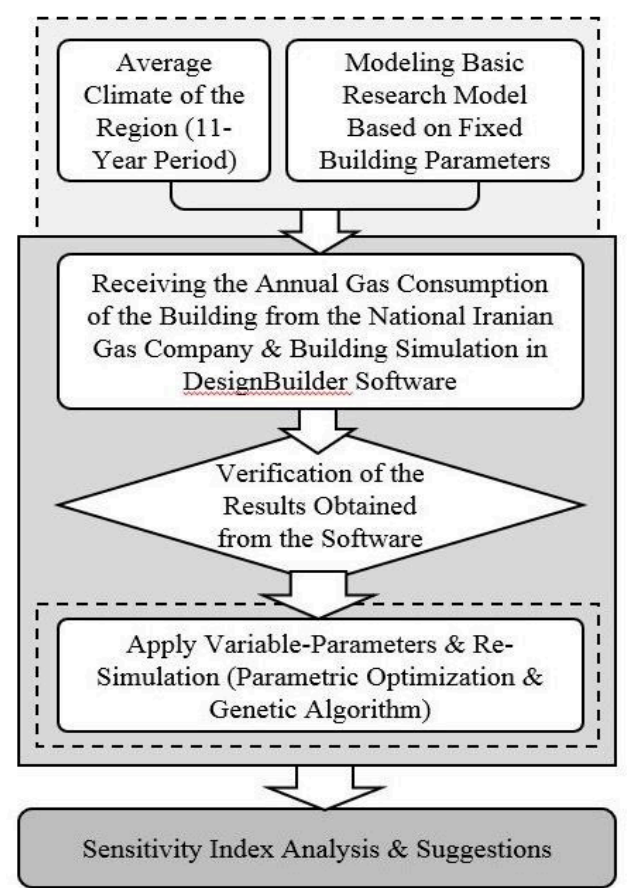

Figure 1. The applied process of research (Source: Authors)

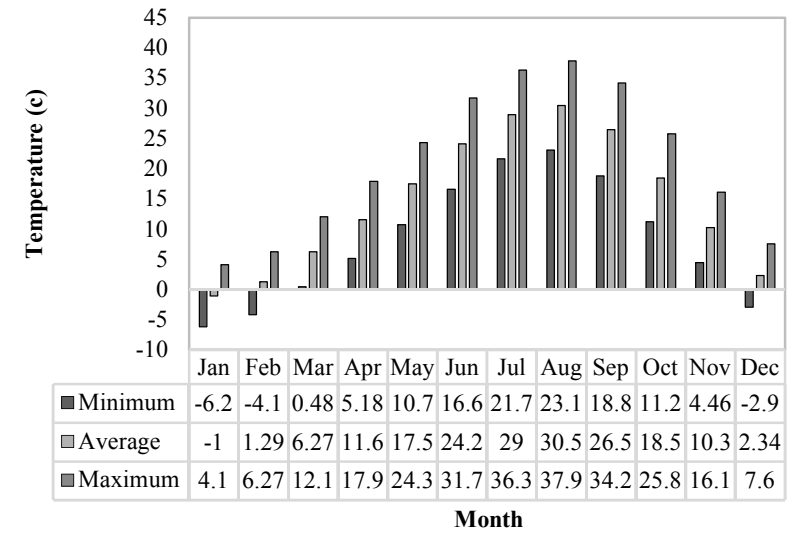

Figure 2. Average of minimum, average, and maximum air temperature in the statistical period of 2009-2020 in Tabriz (Source: Tabriz Meteorological Department, 2021 [22])

\section{SIMULATION OF BASIC RESEARCH MODEL}

\section{Modeling}

Figures 5 and 6 show the perspectives of the building which is modeled in DesignBuilder.

\section{Fixed parameters}

The fixed specifications of the building are provided in Table 1.

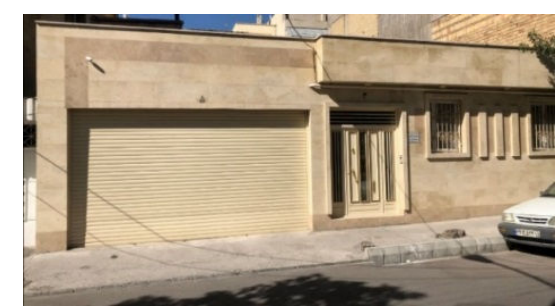

Figure 3. Basic research model (Source: Authors)

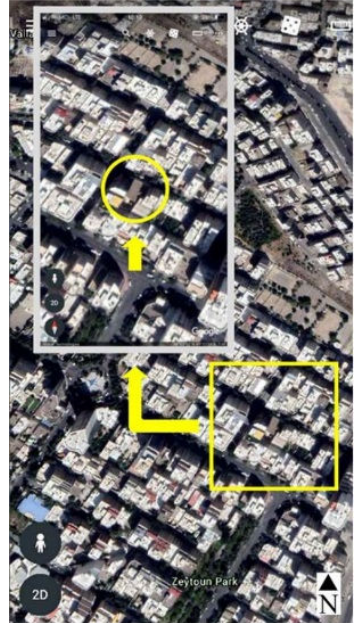

(a)

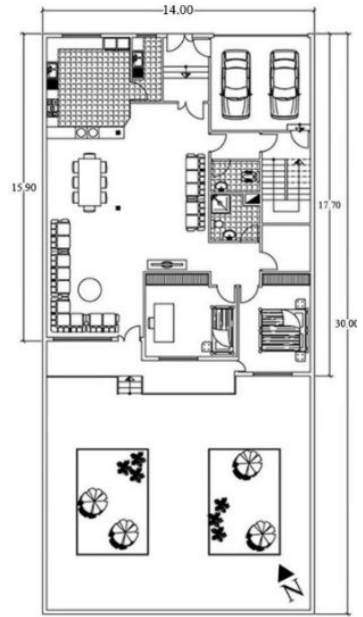

(b)
Figure 4. (a) Aerial photograph (Source: Google Earth, 2020 [23]); (b) Plan (Source: Authors) 


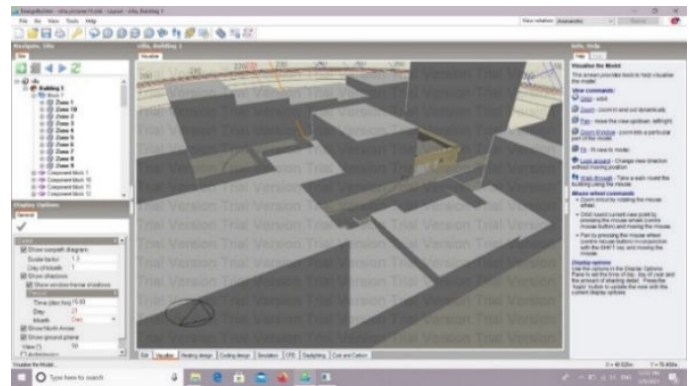

Figure 5. North front of the simulated building (Source: DesignBuilder software, 2020)

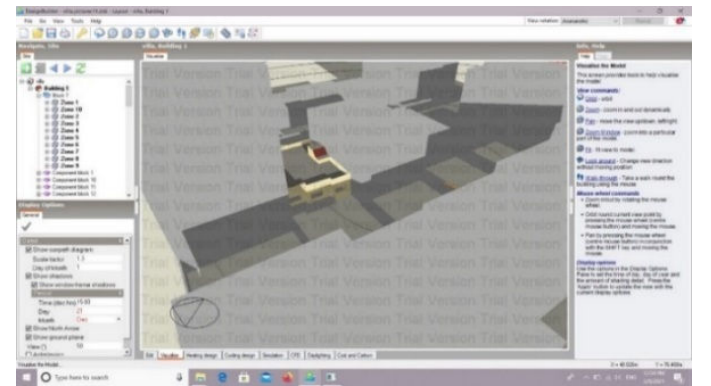

Figure 6. South front of the simulated building (Source: DesignBuilder software, 2020)

Table 1. Characteristics of basic research model (input data related to intervention variables)

\begin{tabular}{|c|c|c|c|c|c|}
\hline \multicolumn{4}{|c|}{ Specifications (Input Data) } & \multicolumn{2}{|c|}{ Performance Coefficient } \\
\hline \multirow{2}{*}{$\begin{array}{l}\text { Number of } \\
\text { residents }\end{array}$} & \multirow{2}{*}{\multicolumn{3}{|c|}{4}} & Activity & Light Activity \\
\hline & & & & Density of People ( $\mathrm{m}^{2}$ per person) & 16 \\
\hline \multirow{8}{*}{$\begin{array}{l}\text { Executive } \\
\text { details }+ \\
\text { thickness }\end{array}$} & \multirow{2}{*}{$\begin{array}{l}\text { Exterior } \\
\text { Walls }\end{array}$} & \multirow{2}{*}{\multicolumn{2}{|c|}{$\begin{array}{l}\text { Travertine stone }(0.015 \mathrm{~m})+\text { Cement mortar }(0.02 \\
\mathrm{m})+ \text { Brick }(0.15 \mathrm{~m})+\text { Gypsum plastering }(0.015 \mathrm{~m})\end{array}$}} & $\begin{array}{l}\text { U-Value (W/m² } k)(\text { Heat Transfer } \\
\text { Coefficient) }\end{array}$ & 2.270 \\
\hline & & & & R-Value $\left(\mathrm{m}^{2} \mathrm{k} / \mathrm{W}\right)$ (Heat Resistance) & 0.440 \\
\hline & \multirow{2}{*}{$\begin{array}{l}\text { Interior } \\
\text { Walls }\end{array}$} & \multirow{2}{*}{\multicolumn{2}{|c|}{$\begin{array}{l}\text { Gypsum plastering }(0.01 \mathrm{~m})+\text { Brick }(0.08 \mathrm{~m})+ \\
\text { Gypsum plastering }(0.01 \mathrm{~m})\end{array}$}} & U-Value & 2.239 \\
\hline & & & & R-Value & 0.447 \\
\hline & \multirow{2}{*}{$\begin{array}{l}\text { Internal } \\
\text { Floor }\end{array}$} & \multirow{2}{*}{\multicolumn{2}{|c|}{$\begin{array}{l}\text { Parquet }(0.025 \mathrm{~m})+\text { Foam under parquet }(0.025 \mathrm{~m}) \\
+ \text { Gypsum and cement mixture }(0.03 \mathrm{~m})+\text { Cement } \\
\text { mortar }(0.02 \mathrm{~m})+\text { Lightweight concrete }(0.1 \mathrm{~m})\end{array}$}} & U-Value & 0.919 \\
\hline & & & & R-Value & 1.088 \\
\hline & \multirow{2}{*}{ Flat Roof } & $\begin{array}{r}\text { Bitumen/felt } \\
\text { m) }+ \text { Light }\end{array}$ & $\begin{array}{l}(0.05 \mathrm{~m})+\text { Cement mortar }(0.02 \\
\text { te }(0.05 \mathrm{~m})+\text { Brick }(0.06 \mathrm{~m})+\end{array}$ & U-Value & 1.363 \\
\hline & & Beam $(0$ & $\begin{array}{l}+ \text { Cement mortar }(0.03 \mathrm{~m})+ \\
\text { a plastering }(0.02 \mathrm{~m})\end{array}$ & R-Value & 0.734 \\
\hline \multirow{14}{*}{ Windows } & \multirow{2}{*}{ Frames } & \multirow{2}{*}{\multicolumn{2}{|c|}{ Aluminium }} & U-Value & 5.876 \\
\hline & & & & R-Value & 0.170 \\
\hline & \multirow{2}{*}{ Dividers } & & Width & Distance $(\mathrm{m})$ & 0.08 \\
\hline & & & Projection & Distance (m) & 0.01 \\
\hline & \multirow{4}{*}{\multicolumn{3}{|c|}{$\begin{array}{l}\text { Type of } \\
\text { Glazing }\end{array}$}} & U-Value & 2.665 \\
\hline & & & & SHGC (Solar Heat Gain Coefficient) & 0.706 \\
\hline & & & & $\mathrm{T}_{\mathrm{v}}$ (Visible Transmittance) & 0.781 \\
\hline & & & & DST (Direct Solar Transmission) & 0.604 \\
\hline & \multicolumn{3}{|c|}{ Elevation } & Area $\left(\mathrm{m}^{2}\right)$ & 56 \\
\hline & \multicolumn{3}{|c|}{ South Windows } & Area $\left(\mathrm{m}^{2}\right)$ & 10.5 \\
\hline & \multicolumn{3}{|c|}{ North Windows } & Area $\left(\mathrm{m}^{2}\right)$ & 4.5 \\
\hline & \multicolumn{3}{|c|}{ WWR } & Percentage $(\%)$ & $\begin{array}{l}8.04 \% \text { (North) } \\
18.75 \% \text { (South) }\end{array}$ \\
\hline & \multicolumn{3}{|c|}{ Sill } & Height (m) & 0.8 \\
\hline & \multicolumn{3}{|c|}{ Reveal } & Outside Depth (m) & 0.1 \\
\hline \multirow{3}{*}{$\begin{array}{l}\text { Heating } \\
\text { System }\end{array}$} & \multirow{2}{*}{\multicolumn{2}{|c|}{$\begin{array}{l}\text { System Type } \\
\text { Fuel Type }\end{array}$}} & \multirow{2}{*}{$\begin{array}{l}\text { Convection - Central Engine } \\
\text { Natural Gas }\end{array}$} & Maximum amount of moisture that can & 0.016 \\
\hline & & & & be provided by the system & 0.010 \\
\hline & \multicolumn{2}{|c|}{$\begin{array}{l}\text { Heat Distribution Units } \\
\text { Fluid type }\end{array}$} & $\begin{array}{l}\text { Radiator } \\
\text { Hot Water }\end{array}$ & $\begin{array}{l}\text { Maximum temperature that can be } \\
\text { provided by the system }(C)\end{array}$ & 35 \\
\hline \multirow{2}{*}{ Lighting } & \multirow{2}{*}{\multicolumn{3}{|c|}{ Suspended LED }} & Radiant Fraction & 0.420 \\
\hline & & & & Visible Fraction & 0.180 \\
\hline Cooling & & Cooler (E & ity - Inverter) & COP (Coefficient of Performance) & 4.5 \\
\hline
\end{tabular}

(Source: DesignBuilder software, 2020) 


\section{Variable parameters in parametric optimization} At this stage, after adapting the simulation results and the real consumption of the building, the form of designing the windows (Proportions and number of windows with the fixed area) will be changed and the simulation will be performed again. Variable parameters for re-simulation in parametric optimization are presented in Table 2.

Table 2. Variable parameters (resize and changing the number of windows) for re-simulation



(Source: Authors, DesignBuilder software, 2020) 
Reasons for selecting variable parameters (window proportions) in parametric optimization The proportions presented in Table 2 for windows have been selected as variable parameters for the following reasons:

- Due to the aesthetics of the building facade, the least height for the window is equal to 1.2 meters and due to the difficulty of implementing high-height windows, the greatest height for the window is 1.74 meters. So, The suggested height for the windows is in the range of 1.2 to 1.74 meters.

- The number of windows has been increased from one window to five, taking into account the total fixed area, to examine the effect of increasing the number of windows on the amount of solar energy received.

\section{Variable parameters in genetic algorithm}

Genetic algorithms are accidence search algorithms whose base is taken from nature. In this algorithm, the offspring genes inherit some aspects of the father and some aspects of the mother gene in a new complex of different gene structures at accidence. In this method, the variables will be randomly selected and simulated. The types of glazing (with aluminium frame) and frame selected for the genetic algorithm are presented in Table 3.

1. Clear double-glazed glazing $(6 \mathrm{~mm}+13 \mathrm{~mm}$ Air +6 $\mathrm{mm})$

2. Clear double-glazed glazing $(6 \mathrm{~mm}+13 \mathrm{~mm}$ Argon gas $+6 \mathrm{~mm}$ )

3. Clear double-glazed glazing (6 mm $+13 \mathrm{~mm} \mathrm{90 \%}$ Argon gas and 10\% Air $+6 \mathrm{~mm}$ )

4. Reflective double-glazed glazing - Tint - $(6 \mathrm{~mm}+13$ $\mathrm{mm}$ Argon gas $+6 \mathrm{~mm}$ )

5. Clear triple-glazed glazing $(3 \mathrm{~mm}+13 \mathrm{~mm}$ Argon gas $+3 \mathrm{~mm}+13 \mathrm{~mm}$ Argon gas $+3 \mathrm{~mm}$ )

6. Low emissivity triple-glazed glazing e $=0.1(3 \mathrm{~mm}+$ $13 \mathrm{~mm}$ Argon gas $+3 \mathrm{~mm}+13 \mathrm{~mm}$ Argon gas $+3 \mathrm{~mm})$. 7. Change the frame from aluminium (basic research model) to UPVC. [glazing: $(6 \mathrm{~mm}+13 \mathrm{~mm}$ Air $+6 \mathrm{~mm})$ ].

Table 3. The type of glazing and frame selected and their properties for simulation and comparison

\begin{tabular}{lcccc}
$\begin{array}{l}\text { Type of Glazing } \\
\text { \& Frame }\end{array}$ & DST & SHGC & $\mathbf{T}_{\mathbf{v}}$ & U-Value \\
\hline 1 & 0.604 & 0.706 & 0.781 & 2.665 \\
2 & 0.604 & 0.704 & 0.781 & 2.511 \\
3 & 0.604 & 0.704 & 0.781 & 2.526 \\
4 & 0.119 & 0.242 & 0.163 & 2.268 \\
5 & 0.595 & 0.685 & 0.738 & 1.620 \\
6 & 0.458 & 0.579 & 0.698 & 1.058 \\
7 & - & - & - & 3.476 \\
\hline
\end{tabular}

(Source: DesignBuilder software, 2020)

\section{Low-emissivity glazing specifications intended for this research}

Low-emissivity (Low-E) glazing was created to minimize the amount of infrared and ultraviolet light that comes from glass, without minimizing the amount of light that enters the home. Low-E coatings minimize heat loss by reflecting back thermal energy which is in the form of long-wavelength radiation back into a building and trap the heat inside. This is favorable for cold conditions. Low-E glazing windows have a microscopically thin coating that is transparent and reflects heat. Transmission and reflectance of Low-E glazing is shown in Figure 7.

It is better that the low-E coating is placed on the surface shown in Figure 8. The cross-section perspective of frames is presented in Figure 9.

\section{RESULTS OBTAINED FROM SIMULATION OF BASIC RESEARCH MODEL IN DESIGNBUILDER SOFTWARE}

Table 4 indicates the results of simulation in the DesignBuilder software.

\section{Validation of results obtained from simulation}

In order to ensure the exactitude of software results and their reliability, the natural gas amount consumed for

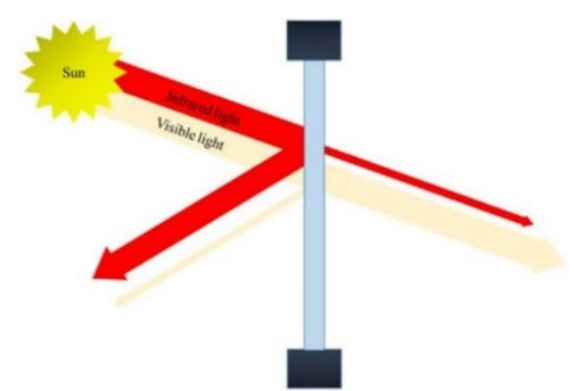

Figure 7. Transmission and reflectance of Low-E glazing [24]

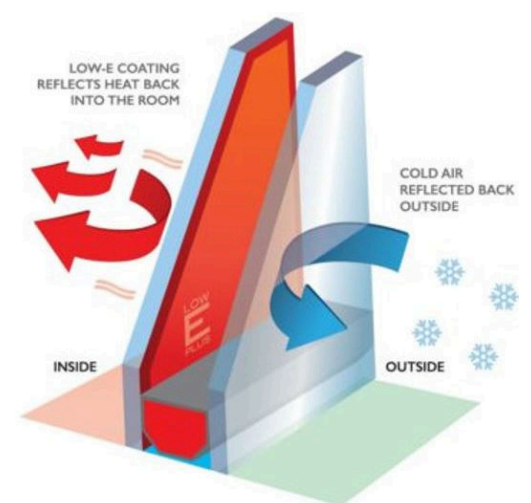

Figure 8. Location of low-E cover in the cold and dry climate of Tabriz [25] 


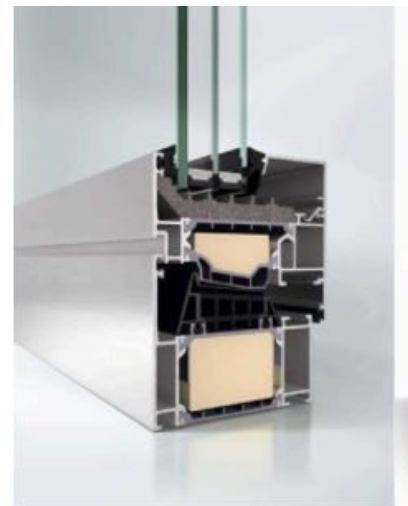

Aluminum

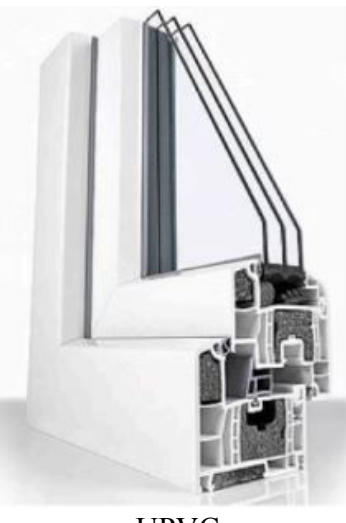

UPVC
Figure 9. Cross-section perspective for Aluminum and UPVC frame options [26]

Table 4. Simulation results

\begin{tabular}{lc}
\hline \multicolumn{2}{c}{ Simulation results (kWh) } \\
\hline Heat loss & 24.74 \\
Heating (gas) & 53147.76 \\
Lighting & 2083.5 \\
Computer \& Equip & 2836.75 \\
DHW (Electricity) & 17715.92 \\
Zone Sensible Heating & 34428.18 \\
Cooling (Electricity) & 1231.08 \\
\hline
\end{tabular}

(Source: DesignBuilder software, 2020)

heating in the building understudy has been attained from the National Iranian Gas Company. As respects that the figures presented by the Gas Company are in $\mathrm{m}^{3}$ and the software outputs are in $\mathrm{kWh}$; with the following process, the software results are converted from $\mathrm{kWh}$ to $\mathrm{kg}$ and then $\mathrm{kg}$ to $\mathrm{m}^{3}$. The heating value of natural gas is $22500 \mathrm{Btu} / \mathrm{lb}(5225 \mathrm{~kJ} / \mathrm{kg})$. Based ideal gas law, assume natural gas is mainly contained methane; $1 \mathrm{~kg}$ of natural gas at standard conditions have volume of $1.3966 \mathrm{~m}^{3}$.

Table 5 indicates the results presented by the National Iranian Gas Company in 11-years (average) and also the simulation outputs of the building.

By reference to the result gained from the conversion of the unit, the actual average annual building consumption is $7590 \mathrm{~m}^{3}$ and the amount received by the EnergyPlus engine is $8300 \mathrm{~m}^{3}$. the discrepancy in values is $8.56 \%$. This indicates that DesignBuilder software computes the gas consumption of building with allowable precision.

\section{Results obtained from parametric optimization}

Results obtained from the simulation in DesignBuilder software (which has been tested based on changing form of windows), Presented in Table 6. It shows the fact that by changing the design form of windows with the total fixed area of windows in the building, the amount of energy consumption changes.

Table 7 shows the graphically of light coming in from the windows (daylighting) and indicates that the height of 1.5 to 1.74 meters is the most suitable height for the window in terms of sunlight entering the interior. In addition to the above, increasing the number of windows with a total fixed area reduces the entry of sunlight into the interior during the day.

Table 5. Building gas consumption

\begin{tabular}{ll}
\hline $\begin{array}{l}\text { Validation of the Results, } \\
\text { Average Annual Gas } \\
\text { Consumption - } \mathbf{~ m}^{\mathbf{3}} \text { - } \\
\text { (11-Year Average) }\end{array}$ & $\begin{array}{l}\text { Simulation of Basic Research } \\
\text { Model Based on Average } \\
\text { Climate of Tabriz - kWh- } \\
\text { (11-Years) }\end{array}$ \\
\hline 7590 & 53147.76 \\
\hline $\begin{array}{l}\text { (Source: National Iranian Gas } \\
\text { Company, 2020) }\end{array}$ & $\begin{array}{l}\text { (Source: Design Builder } \\
\text { Software, 2020) }\end{array}$ \\
\hline
\end{tabular}

Table 6. Results obtained from simulation in software based on fixed and variable parameters

\begin{tabular}{|c|c|c|c|c|c|}
\hline $\begin{array}{l}\text { Design } \\
\text { Form }\end{array}$ & $\begin{array}{l}\text { Heat Loss from } \\
\text { Windows (Wh) }\end{array}$ & $\begin{array}{c}\text { Annual Gas } \\
\text { Consumption for } \\
\text { Heating (kWh) }\end{array}$ & $\begin{array}{l}\text { Annual Electricity } \\
\text { Consumed for } \\
\text { Cooling (kWh) }\end{array}$ & $\begin{array}{l}\text { Annual Electricity } \\
\text { Consumed for } \\
\text { Lighting (kWh) }\end{array}$ & $\begin{array}{c}\text { Annual Solar Gains } \\
\text { Exterior Windows } \\
(\mathbf{k W h})\end{array}$ \\
\hline 1 & 970 & 53147.76 & 1231.08 & 2083.50 & 4329.68 \\
\hline 2 & 980 & 53290.10 & 1225.31 & 2099.60 & 4136.77 \\
\hline 3 & 960 & 53079.25 & 1231.05 & 2025.03 & 4367.68 \\
\hline 4 & 960 & 53073.30 & 1231.02 & 2003.25 & 4383.32 \\
\hline 5 & 990 & 53529.82 & 1197.69 & 2153.21 & 3458.85 \\
\hline 6 & 1020 & 53823.49 & 1169.20 & 2214.87 & 2785.78 \\
\hline 7 & 1050 & 54159.56 & 1140.15 & 2307.54 & 2049.02 \\
\hline 8 & 1080 & 54453.99 & 1115.70 & 2388.96 & 1414.74 \\
\hline
\end{tabular}

(Source: DesignBuilder software, 2020) 
S. Abdoli Naser et al. / Iranian (Iranica) Journal of Energy and Environment 13(1): 27-38, 2022

Table 7. Solar gains exterior windows

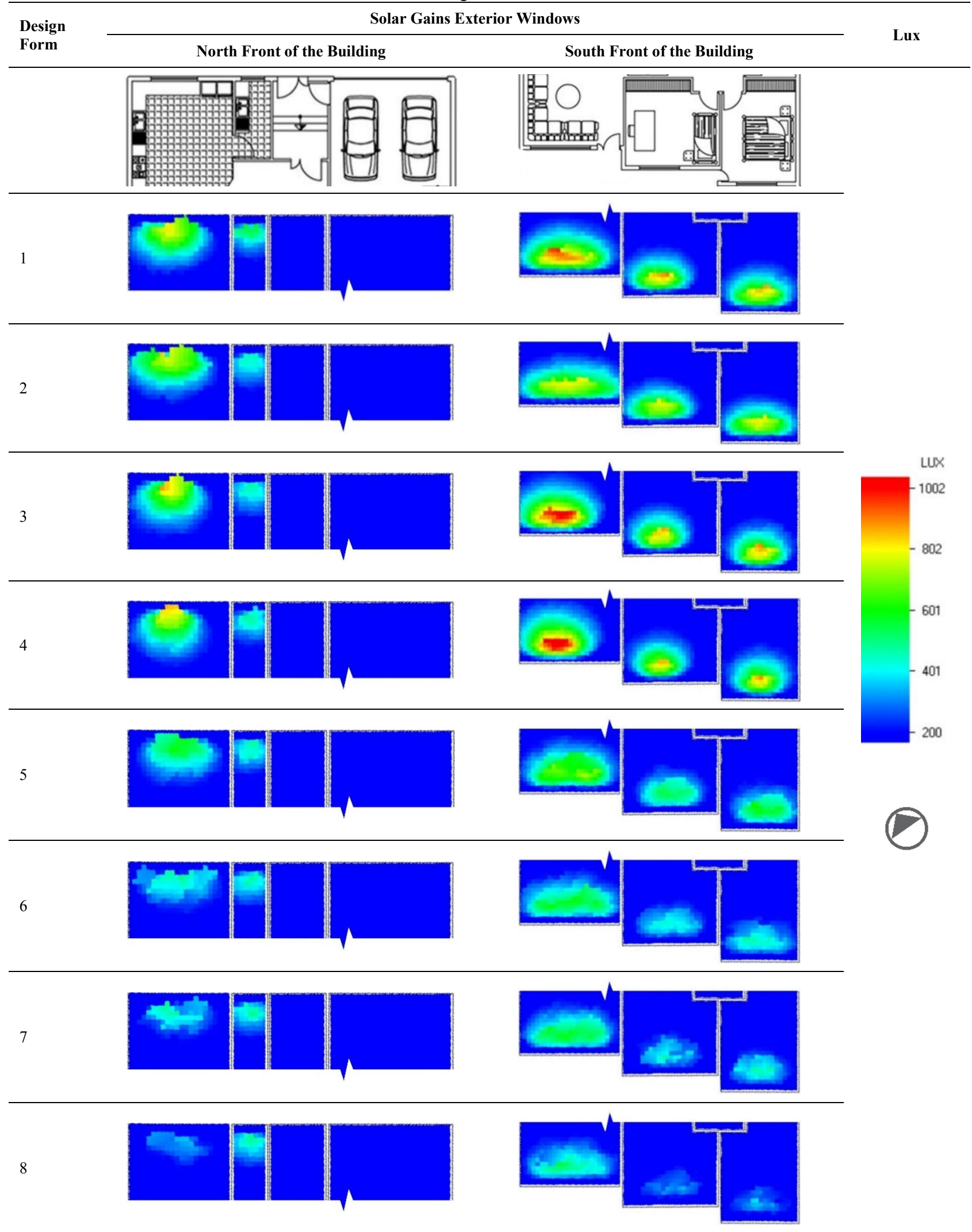

(Source: DesignBuilder software, 2020) 


\section{Results obtained from genetic algorithm}

Results obtained from the simulation in Design Builder software (which has been tested based on changing the glazings), provided in the Table 8.

\section{Results analysis}

Figure 10 indicates the ascending trend of heat loss from windows based on increasing the number of windows (with the total fixed area). Due to the cold climate of Tabriz, forms 3 and 4 (See Table 4 ) are the best design to decrease the amount of heat leakage from the windows, and Figure 11 shows a comparison of the monthly gas consumption for heating the building in simulated designs. Due to the cold climate of Tabriz, forms 3 and 4 are the most suitable design form, and form 8 is the most unsuitable form to reduce the amount of gas consumed for heating.

Figure 12 shows descending trend of heat loss from windows based on changing the glazing, and figure 13 indicates a $7.21 \%$ reduction in heat loss by changing the window frame (considering the same glass).

\section{Results index (sensitivity index)}

In order to investigate the impact of the variables presented in Tables 2 and 3, results from index analysis has been used.

$$
\text { Index }=\frac{\text { Maximum }- \text { Minimim }}{\text { Maximum }} * 100
$$

Table 8. Results obtained from simulation in software based on fixed and variable parameters

\begin{tabular}{lccccc}
$\begin{array}{l}\text { Type of glazing } \\
\text { \& frame }\end{array}$ & $\begin{array}{c}\text { Heat Loss from } \\
\text { Windows (Wh) }\end{array}$ & $\begin{array}{c}\text { Annual Gas } \\
\text { Consumption for } \\
\text { Heating }(\mathbf{k W h})\end{array}$ & $\begin{array}{c}\text { Annual Electricity } \\
\text { Consumed for } \\
\text { Cooling (kWh) }\end{array}$ & $\begin{array}{c}\text { Annual Electricity } \\
\text { Consumed for } \\
\text { Lighting (kWh) }\end{array}$ & $\begin{array}{c}\text { Annual Solar Gains } \\
\text { Exterior Windows } \\
\text { (kWh) }\end{array}$ \\
\hline 1 & 970 & 53147.76 & 1231.08 & 2083.50 & 4329.68 \\
2 & 930 & 53121.37 & 1229.51 & 2088.31 & 4291.72 \\
3 & 940 & 53129.20 & 1229.51 & 2088.31 & 4291.72 \\
4 & 790 & 54340.35 & 1102.78 & 5083.25 & 226.03 \\
5 & 700 & 52760.56 & 1199.87 & 2102.35 & 4135.99 \\
7 & 530 & 52643.54 & 1204.59 & 2451.33 & 3091.42 \\
\hline
\end{tabular}

(Source: DesignBuilder software, 2020)

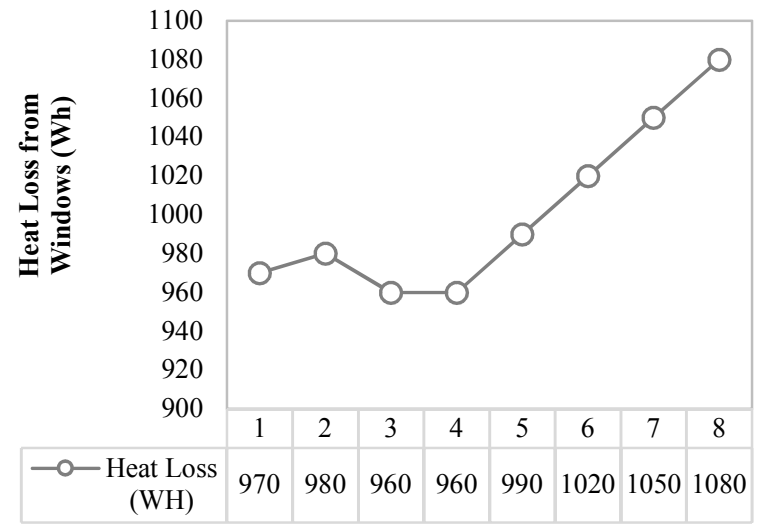

Design Forms

Figure 10. Heat loss from windows (Source: Authors, DesignBuilder software, 2020)

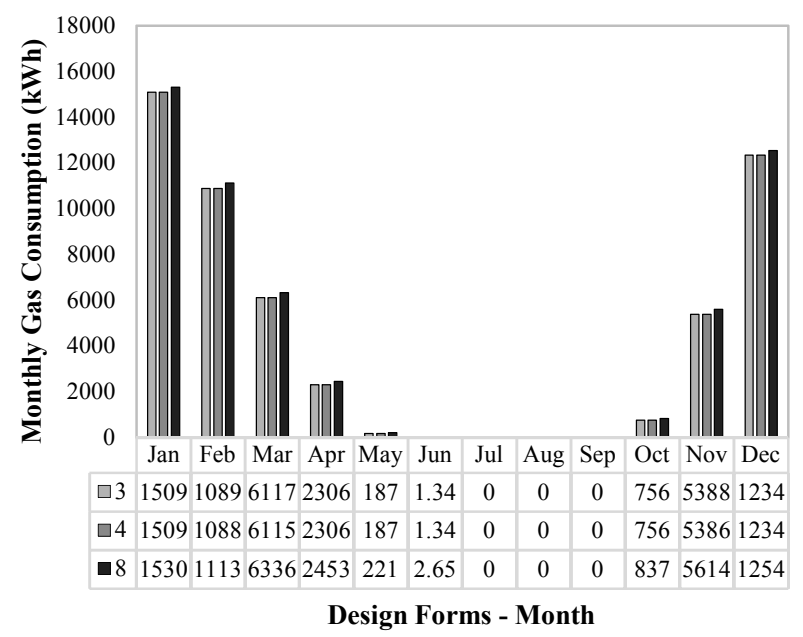

Figure 11. Monthly gas consumption (Source: Authors, DesignBuilder software, 2020) 


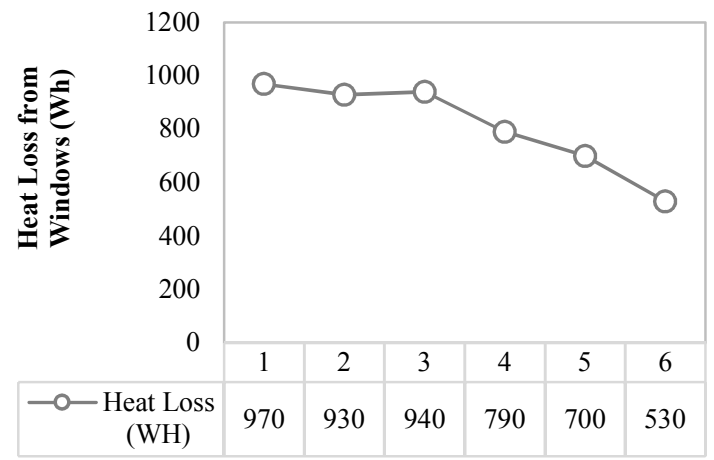

Type of Glazing

Figure 12. Heat loss from windows (Source: Authors, DesignBuilder software, 2020)

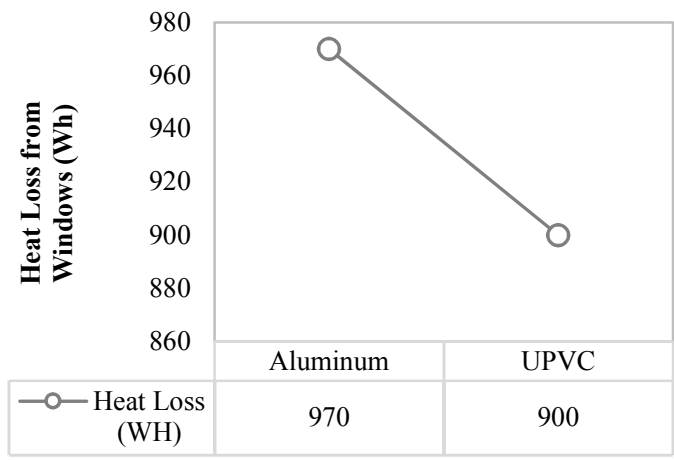

Type of Frame

Figure 13. Heat loss from windows (Source: Authors, DesignBuilder software, 2020)

Table 9. Results index based on variables

\begin{tabular}{|c|c|c|c|c|c|c|}
\hline & Variables & & $\begin{array}{c}\text { Percentage } \\
\text { decrease }(\downarrow)- \\
\text { increase }(\uparrow) \\
\text { in heat loss } \\
(\%)\end{array}$ & $\begin{array}{c}\text { Percentage } \\
\text { decrease }(\downarrow) \text { - } \\
\text { increase }(\uparrow) \text { in the } \\
\text { amount of solar } \\
\text { energy received } \\
\text { annually }(\%)\end{array}$ & $\begin{array}{c}\text { Percentage } \\
\text { decrease }(\downarrow) \text { - } \\
\text { increase }(\uparrow) \text { in } \\
\text { annual electricity } \\
\text { consumption for } \\
\text { cooling }(\%)\end{array}$ & $\begin{array}{c}\text { Percentage } \\
\text { decrease }(\downarrow) \text { - } \\
\text { increase }(\uparrow) \text { in } \\
\text { annual electricity } \\
\text { consumption for } \\
\text { lighting }(\%)\end{array}$ \\
\hline \multirow{5}{*}{$\begin{array}{l}\text { Changing } \\
\text { window } \\
\text { proportions }\end{array}$} & $\begin{array}{l}\text { Window height } \\
\text { (m) }\end{array}$ & $\begin{array}{c}\text { Window } \\
\text { proportions }\left(\mathrm{m}^{2}\right)\end{array}$ & \multirow[t]{2}{*}{ - } & \multirow[t]{2}{*}{ - } & \multirow[t]{2}{*}{-} & \multirow[t]{2}{*}{-} \\
\hline & 1.2 & $1.2 * 2.5$ & & & & \\
\hline & 1 & $1 * 3$ & $1.021 \% \uparrow$ & $4.46 \% \downarrow$ & $0.47 \% \downarrow$ & $0.77 \% \uparrow$ \\
\hline & 1.5 & $1.5 * 2$ & $1.031 \% \downarrow$ & $0.87 \% \uparrow$ & $0.003 \% \downarrow$ & $2.81 \% \downarrow$ \\
\hline & 1.74 & $1.74 * 1.74$ & $1.031 \% \downarrow$ & $1.23 \% \uparrow$ & $0.005 \% \downarrow$ & $3.86 \% \downarrow$ \\
\hline \multirow{6}{*}{$\begin{array}{l}\text { Changing } \\
\text { number of } \\
\text { windows }\end{array}$} & $\begin{array}{l}\text { Number of } \\
\text { windows }\end{array}$ & $\begin{array}{c}\text { Window } \\
\text { proportions }\left(\mathrm{m}^{2}\right)\end{array}$ & \multirow[t]{2}{*}{-} & \multirow[t]{2}{*}{-} & \multirow[t]{2}{*}{-} & \multirow[t]{2}{*}{-} \\
\hline & 1 & $2 * 1.5$ & & & & \\
\hline & 2 & $1 * 1.5$ & $3.031 \% \uparrow$ & $20.81 \% \downarrow$ & $2.71 \% \downarrow$ & $5.96 \% \uparrow$ \\
\hline & 3 & $0.67 * 1.5$ & $5.89 \% \uparrow$ & $36.22 \% \downarrow$ & $5.03 \% \downarrow$ & $8.58 \% \uparrow$ \\
\hline & 4 & $0.5 * 1.5$ & $8.58 \% \uparrow$ & $53.09 \% \downarrow$ & $7.39 \% \downarrow$ & $12.25 \% \uparrow$ \\
\hline & 5 & $0.4 * 1.5$ & $11.11 \% \uparrow$ & $67.61 \% \downarrow$ & $9.37 \% \downarrow$ & $15.24 \% \uparrow$ \\
\hline \multirow{7}{*}{$\begin{array}{l}\text { Changing } \\
\text { the type of } \\
\text { glazing and } \\
\text { frame }\end{array}$} & \multirow{6}{*}{ Glazings } & 1 & - & - & - & - \\
\hline & & 2 & $4.12 \% \downarrow$ & $0.87 \% \downarrow$ & $0.12 \% \downarrow$ & $0.23 \% \uparrow$ \\
\hline & & 3 & $3.09 \% \downarrow$ & $0.87 \% \downarrow$ & $0.12 \% \downarrow$ & $0.23 \% \uparrow$ \\
\hline & & 4 & $18.55 \% \downarrow$ & $94.77 \% \downarrow$ & $10.42 \% \downarrow$ & $59.01 \% \uparrow$ \\
\hline & & 5 & $27.83 \% \downarrow$ & $4.47 \% \downarrow$ & $2.53 \% \downarrow$ & $0.89 \% \uparrow$ \\
\hline & & 6 & $45.36 \% \downarrow$ & $28.59 \% \downarrow$ & $2.15 \% \downarrow$ & $15 \% \uparrow$ \\
\hline & Frames & 7 & $7.21 \% \downarrow$ & - & $0.04 \% \downarrow$ & - \\
\hline
\end{tabular}

(Source: Authors)

\section{CONCLUSIONS}

The main target of this research was to ameliorate the decision-making process in the residential building design and execution in a cold climates. The most impressive decisions for the building design process are taken in this step to develop environmentally responsive objectives. Due to the fact that Building facades play an 
effective role in reducing natural gas and electricity consumption because they are the boundary between the interior and exterior of the building and considering that about a third of the heat loss of buildings from windows occurs and if the serious mensuration is not taken, it will afford heat dissipation. So, efforts to decrease energy consumption in residential buildings are focused. Therefore, the research objective was accessing the suitable model of fenestration pattern by using parametric optimization and genetic algorithm. Meanwhile, DesignBuilder software facilitates to assessment of heat dissipation of different sections of the building .

In accordance with the gained outputs, the third and fourth design type and triple-glazed glazing with Low-E coating filled with argon gas and UPVC frame are the best types of window design and performance to diminution window heat dissipation, decrease gas consumption and reduce $\mathrm{CO}_{2}$ emissions. Therefore, to reconsider the design and execution of windows and reduce fossil fuel consumption, the following offers are presented in window design and performance in the building facades: - By changing the height of the window from 1 meter to 1.5 meters, heat loss is reduced by $2.04 \%$ per hour.

- By changing the number of windows from one window to two windows (with the equal total area), heat loss increased by $3.03 \%$, and by changing the number of windows from one window to five windows, the amount heat losses increased by $11.11 \%$ per hour.

- Changing the height of the window from 1 meter to 1.74 meters increases the solar energy rate received annually by $5.62 \%$.

- Changing the number of windows (from one window to five windows with the equal area) reduces the amount of solar energy received annually by $67.61 \%$.

- Considering the fixed area, windows with a height of 1.5 to 1.74 meters should replace windows with a height of 1 or 1.2 meters.

- By replacing triple-glazed glazing with low emission coating e $=0.1(3 \mathrm{~mm}+13 \mathrm{~mm}$ Argon gas $+3 \mathrm{~mm}+13$ $\mathrm{mm}$ Argon gas $+3 \mathrm{~mm}$ ) with current windows (clear double-glazed glazing filled with air) reduces heat dissipation by $45.36 \%$.

- Window arrangements have a substantial effect on energy efficiency. Therefore for each space, one window should replace by $2,3,4$, or 5 windows.

Changing the design form of windows from form 8 (the most inappropriate form) to form 3 (the most appropriate form) causes a decrease in annual gas consumption by $2.5 \%$, annual carbon dioxide emitted from the building as a result of gas consumption for heating by $1.26 \%$. Form 8 compared to form 3 reduces the annual electricity consumption for space cooling by $9.37 \%$ and is suitable for hot climates.

- In order to reduce heat loss, it is better to use tripleglazed glazing with low emission coating and UPVC frames in cold and dry climates.
The mentioned contents proved that due to the fact that several alternatives are derived from the parametric optimization and genetic algorithm, designers can freely choose an alternative according to requirements that are appropriate to any specific design project. The limitation of this research based on the influential variables in the search is as follows: Because the parametric optimization and the genetic algorithm methods require a lot of time and robust computer hardware to accomplish computational models in order to be comprehensive and complete, it is essential to simplify the basic research model by contemplation the assumptions that compute the computational models. Actually does it with less precision.

\section{REFERENCES}

1. Eslami, M. and Nahani, P. 2021, "How Policies Affect the CostEffectiveness of Residential Renewable Energy in Iran: A TechnoEconomic Analysis for Optimization." Utilities Policy, 72, pp. 113. https://doi.org/10.1016/j.jup.2021.101254

2. Balali, A. H., Hakimelahi, A. and Valipour, A. R. 2020 , "Identification and Prioritization of Passive Energy Consumption Optimization Measures in the Building Industry: An Iranian Case Study." Building Engineering, 30, pp. 1-34. https://doi.org/10.1016/j.jobe.2020.101239

3. Bao, H. X. H. and Haotong Li, S. 2020, "Housing Wealth and Residential Energy Consumption.” Energy Policy, 143, pp. 1-13. https://doi.org/10.1016/j.enpol.2020.111581

4. Zhang, SH., Hu, W., Li, D., Zhang, CH., Arici, M., Yildiz, C., Zhang, X. and Ma, Y. 2021, "Energy Efficiency Optimization of PCM and Aerogel-Filled Multiple Glazing Windows." Energy, 222, pp. 1-14. https://doi.org/10.1016/j.energy.2021.119916

5. Zekraoui, D. Zemmouri, N. 2017, "The Impact of Window Configuration on the Overall Building Energy Consumption under Specific Climate Conditions." Energy Procedia, 115, pp. 162-172. https://doi.org/10.1016/j.egypro.2017.05.016

6. Lechowska, A. A., Schnotale, A., Jacek, A. and Baldinelli, G. 2017, "Window Frame Thermal Transmittance Improvements Without Frame Geometry Variations: An Experimentally Validated CFD Analysis." Energy and Buildings, 145, pp. 188199. https://doi.org/10.1016/j.enbuild.2017.04.002

7. Khalesi, J. and Goudarzi, N. 2018, "Thermal Comfort in a Climate-Adaptive Building with Smart Windows and Different Outlet Opening Location." Sustainable Cities and Society, Accepted Manuscript, pp. 1-32. https://doi.org/10.1016/j.scs.2018.11.029

8. Hasan, S., Usmani, J. A. and Islam, M. 2018, "Simulation of Energy Conservation in a Building: A Case Study." Iranian Journal of Energy and Environment, Vol. 9, No. (1), pp. 10-15. Doi: 10.5829/ijee.2018.09.01.02

9. Potrc Obrecht, T., Premrov, M. and Zegarac Leskovar, V. 2019, "Influence of the Orientation on the Optimal Glazing Size for Passive Houses in Different European Climates (for non-Cardinal Directions)." Solar Energy, 189, pp. 15-25. https://doi.org/10.1016/j.solener.2019.07.037

10. Kaasalainen, T., Makinen, A., Lehtinen, T., Moisio, M. and Vinha, J. 2020, "Architectural Window Design and Energy Efficiency: Impacts on Heating, Cooling and Lighting Needs in Finnish Climates." Building Engineering, 27, pp. 1-31. https://doi.org/10.1016/j.jobe.2019.100996 
11. Zhou, Y. and Zheng, S. 2020, "Uncertainty Study on Thermal and Energy Performances of a Deterministic Parameters Based Optimal Aerogel Glazing System Using Machine-Learning Method." Energy, 193, pp. 1-14. https://doi.org/10.1016/j.energy.2019.116718

12. Abdoli Naser, S., Haghparast, F., Singery, M. and Sattari Sarbangholi, H. 2020, "Providing an Optimal Execution Model for Windows Based on Glazing to Reduce Fossil Fuel Consumption (Case Study: Asman Residential Complex of Tabriz)." Iranian Journal of Energy and Environment, 11 (4), pp. 260-270. Doi: 10.5829/ijee.2020.11.04.03

13. Saadatian, SH., Freire, F. and Simoes, N. 2021, "Embodied Impacts of Window-Systems: A Comparative Assessment of Framing and Glazing Alternatives." Building Engineering, 35, pp. 1-35. https://doi.org/10.1016/j.jobe.2020.102042

14. Jiang, W., Liu, B., Li, Q., Li, D. and Ma, L. 2021, "Weight of Energy Consumption Parameters of Rural Residences in Severe Cold Area." Case Studies in Thermal Engineering, 26, pp. 1-14. https://doi.org/10.1016/j.csite.2021.101131

15. Sadafi, N., Jamshidi, N. and Zahedian, M. 2021, "Energy Efficient Design Optimization of a Building Envelope in a Temperate and Humid Climate." Iranian Journal of Energy and Environment, 12 (3), pp. 255-263. Doi: 10.5829/ijee.2021.12.03.10

16. Abdoli Naser, S., Haghparast, F., Singery, M. and Sattari Sarbangholi, H. 2021, "Optimization of Thermal Performance of Windows in Intermediate Housing in Cold and Dry Climate of Tabriz." Iranian Journal of Energy and Environment, 12 (4), pp. 327-336. Doi: 10.5829/ijee.2021.12.04.06

17. Huang, J., Wang, Q., Chen, X., Xu, SH. And Yang, H. 2021, "Experimental Investigation and Annual Overall Performance Comparison of Different Photovoltaic Vacuum Glazings.' Sustainable Cities and Society, 75, pp. 1-13. https://doi.org/10.1016/j.scs.2021.103282
18. Tushar, Q., Bhuiyan, M. A. and Zhang, G. 2021, "Energy Simulation and Modeling for Window System: A Comparative Study of Life Cycle Assessment and Life Cycle Costing." Journal of Cleaner Production, In Press. https://doi.org/10.1016/j.jclepro.2021.129936

19. Abdoli Naser, S., Haghparast, F., Singery, M. and Sattari Sarbangholi, H. 2021, "Investigating on Evolution of Windows from Qajar to Pahlavi Era in Tabriz's Ganjei-Zade House with Heat Dissipation Approach." Iranian Journal of Energy and Environment, $12 \quad$ (3), pp. 226-233. Doi: 10.5829/ijee.2021.12.03.07

20. Bagheri Sabzevar, H. and Erfan, Z. 2021, "Effect of Fixed Louver Shading Devices on Thermal Efficiency." Iranian Journal of Energy and Environment, 12 (4), pp. 349-357. Doi: 10.5829/ijee.2021.12.04.08

21. Eskin, N. and Turkmen, H. 2008, “Analysis of Annual Heating and Cooling Energy Requirements for Office Buildings in Different Climates in Turkey." Energy and Buildings, 40 (5), pp. 763-773. https://doi.org/10.1016/j.enbuild.2007.05.008

22. Tabriz (East Azarbaijan) Meteorological Department, 2021.

23. https://earth.google.com/

24. Daqiqeh Rezaei, S., Shannigrahi, S. and Ramakrishna, S. 2017, “A Review of Conventional, Advanced, and Smart Glazing Technologies and Materials for Improving Indoor Environment." Solar Energy Materials and Solar Cells, 159, pp. 26-51. https://doi.org/10.1016/j.solmat.2016.08.026

25. https://www.energlaze.ie/low-e-plus/, date and time of visit: December 3, 2021, 10:32 a.m.

26. Paulos, J. and Berardi, U. 2020, "Optimizing the Thermal Performance of Window Frames through AerogelEnhancements." Applied Energy, 266, pp. 1-18. https://doi.org/10.1016/j.apenergy.2020.114776

\section{COPYRIGHTS}

(C2021 The author(s). This is an open access article distributed under the terms of the Creative Commons Attribution (CC BY 4.0), which permits unrestricted use, distribution, and reproduction in any medium, as long as the original authors and source are cited. No permission is required from the authors or the publishers.

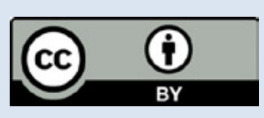

$$
\begin{aligned}
& \text { بيشتر ساختمانهاى امروزى، به علت الكَوبردارى نادرست از معمارى ساختمانهاى كشورهاى ديكًر، مجبور به استفاده از انرزى بيشتر براى ايجاد شرايط آسايش }
\end{aligned}
$$

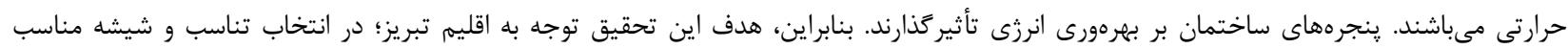

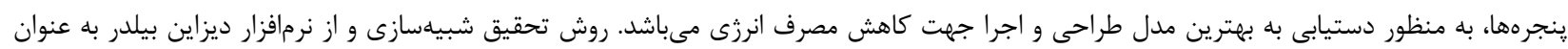

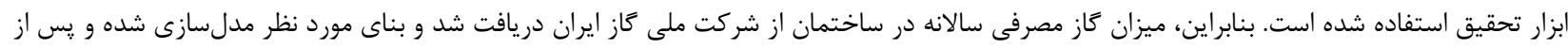

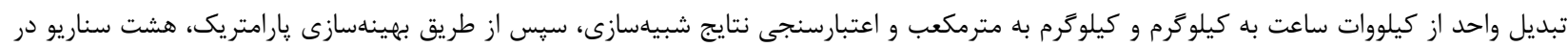

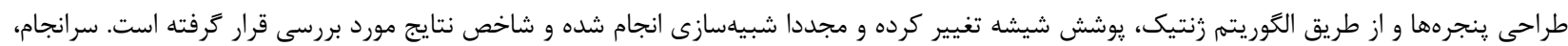

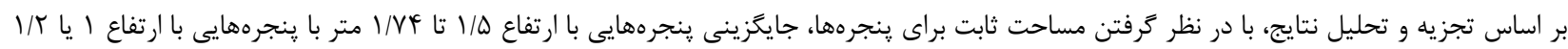

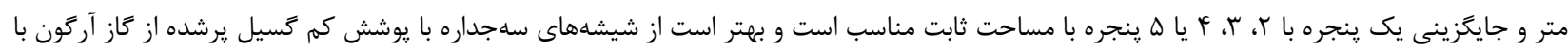

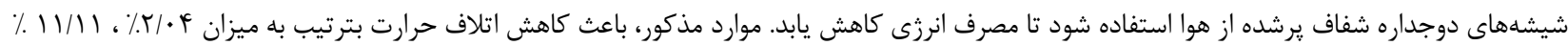

$$
\begin{aligned}
& \text { و و }
\end{aligned}
$$

